\title{
Factors Affecting Nursing Student's Satisfaction with E- Learning Experience in King Khalid University, Saudi Arabia
}

\author{
Wafaa Gameel Mohamed Ali \\ Assist. Prof of Adult Care Nursing, Faculty of Nursing, Mansoura University, and affiliated to \\ Faculty of Nursing, King Khalid University as Assist. Prof of Medical Surgical Nursing, \\ E- mail: drwafaaali@yahoo.com
}

Accepted: February 5, 2012 Published: April 21, 2012

Doi:10.5296/ijld.v2i2.1666 URL: http://dx.doi.org/10.5296/ijld.v2i2.1666

\begin{abstract}
Background; the use of information technology and the internet as teaching and learning tool is rapidly expanding into today's learning environments. Education institutions in the Kingdom of Saudi Arabia (KSA) are preparing students for a rapidly changing information and technology driven world. The KSA needs graduates who are ready for the workplace and who have a high level of knowledge and confidence in the use of technology to help them in their lifelong learning. Since e- learning is conducted using the Internet and World Wide Web, the learning environment becomes more complicated. Students' initial perceived satisfaction with technology-based e- learning will determine whether they will use the system continually. So this study aimed to assess perceived e-learner satisfaction and investigate the preceding factors influence on nursing students' satisfaction with e-learning experience in King Khalid University. Subjects: A convenience sample of 135 female nursing students affiliated to University Center for Female Studies, King Khalid University was enrolled in this study. Tool: data were collected by using three tools. The first was concerned with collecting data related to sample characteristics, the second concerned with identifying the factors that may affect the e-learner satisfaction with e-learning. The third concerned with measuring the learner satisfaction with e-learning. Results; revealed that $61.5 \%$ of participant students were unsatisfied with their e-learning experience and learner attitude towards computer, learners' computer anxiety, e-learning course flexibility, e- learning course quality, technology quality, perceived usefulness, perceived ease of use, diversity in assessment, and learner perceived interaction with others were the critical factors affecting learners' perceived satisfaction.
\end{abstract} Recommendation \&implications: Helping students build their confidence in using computers 
will make e- learning more enjoyable. Also course content should be relevant, logically organized, easy to use, carefully designed, and presented sparingly. The results show institutions how to improve learner satisfaction and further strengthen their e- learning implementation.

Key words: E-learning, E- learner Satisfaction, Factors Affecting E- learner Satisfaction. Introduction:

Technology has inevitably become the most powerful tool in almost every aspect of human's daily life. Technology is regarded as a major revolution and this has a significant impact on education. The use of Information Technology (IT) and the Internet are the new paradigm of learning in 21 st century. These technological advancements allow people to easily access, gather, analyze, and transfer data \& knowledge. This makes it possible for them to function as teachers, study-mates and more importantly, as tools to improve entire teaching and learning process ${ }^{(1)}$. Learning communities have evolved from the traditional classroom to online distance education settings in which students come together in a virtual environment to exchange ideas, solve problems, explore alternatives, and create new meanings along a connected journey ${ }^{(2-3)}$.

Furthermore e-learning is a useful tool for enhancing the quality of teaching and learning. It is an "innovative approach to education delivery via electronic forms of information that enhance the learner's knowledge and skills ${ }^{(4)}$. Arbaugh (2002) ${ }^{(5)}$ defined e-learning as the use of the Internet by users to learn specific content. Other researchers define e-learning as using modern Information and Communications Technology (ICT) and computers to deliver instruction, information, and learning content ${ }^{(6)}$. In nursing education, the move toward integrating distance education and Web-based learning into curricula continues as students and faculty experience the effects of distance education technologies on teaching and learning. Just as in classroom settings, nursing programs delivered by distance education can involve students as co participants who shape learning through inquiry ${ }^{(7)}$.

Advantages of e-learning for learners include increase accessibility to information, better content delivery, personalized instruction, content standardization, accountability, on-demand availability, self-pacing, interactivity, confidence, and increased convenience. Among other benefits for faculty, e-learning reduces costs because it reduces classroom and facilities cost, training cost, travel cost, printed materials cost, and labor cost. Also it enables a consistent delivery of content, improves tracking, and information overload. ${ }^{(8-11)}$.

Despite these benefits, e-learning has a higher drop-out rate than traditional delivered instruction ${ }^{(10)}$. Little is known about why some users stop their online learning after their initial experience. Information system research clearly shows that user satisfaction is one of the most important factors in assessing the success of system implementation ${ }^{(12)}$. In an e-learning environment, several factors account for users' satisfaction. Those factors can be categorized into six dimensions: student, teacher, course, technology, system design, and environmental dimension ${ }^{(5,13-18)}$.

Under the six dimensions previously identified, thirteen factors were involved. In the learner dimension those factors are learner attitude toward computers, learner computer anxiety, and learner Internet self-efficacy E- learning course flexibility, e- learning course quality in the course dimension are identified. The technology dimension factors were 
technology quality and Internet quality. Finally, perceived usefulness and perceived ease of use were identified in design dimension and diversity in assessment and learner perceived interaction with others in the environmental dimension ${ }^{(19)}$.

Because of E-learning depends mainly on the use of computers as assisting tools, a more positive attitude toward IT will result in more satisfied and effective learners in an e-learning environment. In reverse, computer anxiety and fears of computer usage would certainly hamper learning satisfaction ${ }_{(16)}$. Barbeite \& Weiss, $(2004){ }^{(20)}$ stated that computer anxiety is "an emotional fear of potential negative outcomes such as damaging the equipment or looking foolish'. Users' anxiety is different from attitude which represents beliefs and feelings toward computers ${ }^{(19)}$. Self-efficacy is individuals' inclination toward a particular functional aspect. It is an evaluation for effects and the possibility of success before performing a task ${ }^{(21)}$. Learners with high self-efficacy are more confident in accomplishing e- learning activities and improving their satisfaction ${ }^{(19)}$.

The quality of e- learning courses is also considered a significant factor in learner satisfaction. Participation and satisfaction of e-learners are facilitated due to e-learning courses' flexibility in time, location, and methods ${ }^{(5,22)}$. In addition to the virtual characteristics of e-learning, including online interactive discussion and brainstorming, multimedia presentation for course materials, and management of learning processes, assist learners in establishing learning models effectively and motivating continuous online learning. Therefore the quality of well-designed e-learning programs is the precedent factor for learners when considering e-learning ${ }^{(16)}$. The definition of e-learning course flexibility is learners' perception of the efficiency and effects of adopting e-learning in their working, learning, and commuting hours.

Several researchers indicate that technology quality and Internet quality significantly affect satisfaction in e-learning ${ }^{(16 ; 23)}$. A software tool with user-friendly characteristics, such as learning and memorizing few simple ideas and meaningful keywords, demands little effort from its users. Users will be willing to adopt such a tool with few barriers and satisfaction will be improved. Therefore, the higher the quality and reliability in IT, the higher the learning effects will be ${ }^{(16)}$. Also previous studies confirmed that the more learners' perceive usefulness and ease of use in courses delivering media, such as course websites and file transmitting software, the more positive their attitudes are toward e-Learning, consequently improving their learning experiences and satisfaction, and increasing their chances for using e- learning in the future $^{(2,13,24)}$. Learner perceived usefulness in an e-learning system is defined as the perception of degrees of improvement in learning effects because of adoption of such a system. Perceived ease of use in an e-learning system is learners' perception of the ease of adopting an e-learning system.

Furthermore proper feedback mechanisms are important to e-learners. Environmental variables such as diversity in assessment and perceived interaction with others considerably influence e-learning satisfaction ${ }^{(17)}$. The use of different evaluation methods in an e-learning system causes users to think that a connection is established between them and the instructors, and their learning efforts are properly assessed. In a virtual learning environment, interactions between learners and others or course materials can help solve problems and improve progress. Interacting electronically could improve learning effects ${ }^{(16,25)}$. Many researchers agree that 
interactive instructional design is an essential factor for learning satisfaction and success (26, 19). There are three kinds of interactions in learning activities: students with teachers, students with materials, students with students. Without clear interactions between teachers and students, learners are more prone to distractions and difficulty concentrating on the course materials ${ }^{(27)}$.

Finally, education institutions in the Kingdom of Saudi Arabia (KSA) are preparing students for a rapidly changing information and technology driven world. The KSA needs graduates who are ready for the workplace and who have a high level of knowledge and confidence in the use of technology to help them in their lifelong learning. Since e- learning is conducted using the Internet and World Wide Web, the learning environment becomes more complicated. Perceived e-Learner satisfaction is widely used in evaluating effects of learning environments and activities both academically and practically ${ }^{(28)}$. Also, it is used as a key indicator of whether or not learners would continue to adopt a learning system ${ }^{(5)}$. This study intends to assess e- learning effects through measuring learner satisfaction and investigate the preceding factors' influences on their satisfaction.

\section{Aims of the study:}

The present study aimed to assess perceived e-learner satisfaction level and investigate the preceding factors influence on nursing students' satisfaction with e-learning experience in King Khalid University.

\section{Subjects and Methods:}

Research design; Descriptive exploratory design was used Setting:

The study was conducted at the Faculty of Nursing, King Khalid University, Saudi Arabia.

\section{Subjects:}

A convenience sample of 135 nursing students from the faculty of nursing, King Khalid University was enrolled in this study. All levels of the academic year 1432- 1433 were represented in this study. It comprised 28 students from 7th level, 45 students from the 5th level, 24 students from the 4th level, and 38 from the 3 rd level. All study subject experience e learning through one course or more.

\section{Tool of data collection}

The data were collected by using three tools.

The first tool is concerned with collecting data related to student academic level, title and number of course take it through e learning, and if she prefer to study again through e learning or not.

The second tool is a self administered questionnaire, developed by ${ }^{(19)}$. It concerned with investigating the factors that may affect the e-learner satisfaction with e-learning. It consistent of 68 items with response options of strongly disagrees, disagree, uncertain, agree, and strongly agree except for learner internet self- efficacy subscale the response options were not at all confident (0), moderately confident (.5), and totally confident (1). Positive items are scored one (strongly disagree) to five (strongly agree). Scores are reversed for negative items. The 
questionnaire divided into 11 subscales namely as a following: learner attitude toward Computers (8 items), learner computer anxiety ( 4 items), learner internet self- efficacy (12 items), E- learning course flexibility (8 items), learning course quality (3 items), technology quality (4 items), internet quality (4 items), Design dimension Perceived usefulness (3 items), Perceived ease of use ( 2 items), Environmental dimension Diversity in assessment (1item), Learner Perceived interaction with Others (9 items).

The third tool is developed by Arbaugh (2000) ${ }^{(22)}$ and concerned with measuring the level of learner satisfaction with $\mathrm{E}$ - Learning and consistent of 9 items with response options of strongly disagrees, disagree, uncertain, agree, and strongly agree. Positive items were scored one (strongly disagree) to five (strongly agree) but scores were reversed for negative items. The levels of learner satisfaction were classified as follow; unsatisfied $\geq 60 \%$ and satisfied $<60 \%$ of the total score of e-learning satisfaction scale.

\section{Methods of data collection}

1- An official approval was obtained from the Dean of the Faculty of Nursing King Khalid University after explanation of study' aim.

2- The second and third tools were translated into Arabic by researcher

3- A jury of 5 experts in the field of nursing was done to ascertain the content validity of the tools and necessary modifications were carried out accordingly.

4- A pilot study was carried out on 10 nursing students were chosen randomly to ensure the clarity and applicability of the tools.

5- The second and third tools were tested for its reliability after translation. Test and retest reliability was computed using a small sample of nursing students (10) and it was satisfactory for research purposes ( $\mathrm{r}=0.83$ and 87 ).

6- Data were collected through interviewing the students. Each student took 5-10 minutes to complete the questionnaires. The researchers take verbal consent from the participants after explanation of the purpose of the study.

7- The study questionnaire was distributed late by the end of the first semester of the academic year 2011-2012.

$8-$

\section{Data Analysis}

Data was analyzed using statistical Package for social sciences version 15.0. Descriptive statistics were used to analyze the demographic data and data related to study variables. Pearson correlation was used to test the relationship between perceived e-learner satisfaction and factors assumed to affect e-learning student satisfaction.

\section{Results:}

Table (1) shows the distribution of subjects according to their demographic characteristics. As shown the sample consisted of 135 students; third of the sample (33.4\%) from the $5^{\text {th }}$ level and more than half of the sample $(50.6 \%)$ did not prefer to use E learning in their nursing study again while the next half did. Also $56.4 \%$ of the sample had 3 courses or more through Black board and most of them take medical surgical course through Black board.

Table 2; shows the descriptive statistics of the factors affecting e-learning experience as perceived by nursing students and perceived e-learner satisfaction. It showed that the high percentage $(75.1 \%)$ was for learner internet self- efficacy as perceived by participants followed 
by learner attitude toward computers $65.3 \%$. This means that the majority of participants' scored high in those subscales. On the other hand, the least percentage 52.9\% was for Elearning course quality. This means that the majority of the sample perceived that the Elearning courses they pass had moderate quality. In relation to perceived e-learner satisfaction, the majority of participants' scores were around the half $(53.3 \%)$.

Table 3; represent the relationship between dependent variable (perceived e- learner satisfaction) and the independent variables in the study (factors may affect e- learner satisfaction). It showed that there was a positive relationship between learner attitude toward computers and student's satisfaction with E- Learning $\left(\left(\mathrm{r}=.188^{*}\right)\right.$ but there was a strong negative relationship between student's computer anxiety and student's satisfaction with ELearning $\left(-.278^{* *}\right)$. Also it showed a strong positive relationship between student's level of elearning satisfaction and e- learning course flexibility, e- learning course quality, technology quality, perceived usefulness, perceived ease of use, diversity in assessment, and learner perceived interaction with others values of $(\mathrm{r})$ were $.557^{* *}, .656^{* *}, .405^{* *}, .408^{* *}, .363^{* *}$, $.459^{* *}$, and $.259^{* *}$, respectively.

Figure 1: represents participant students' perceived e-learning satisfaction levels. As shown more than half of participants $(61.5 \%)$ unsatisfied with their $\mathrm{Bb}$ or e-learning experience wherever, only $38.5 \%$ were satisfied with e-learning experience as measured by e-learning satisfaction scale.

Table (1): Characteristics of the study subjects $N=135$

\begin{tabular}{|c|c|c|}
\hline Character & Frequency $N=135$ & Percent \\
\hline \multicolumn{3}{|l|}{ Student's academic level } \\
\hline 3rd level & 38 & 28.1 \\
\hline 4th level & 24 & 17.8 \\
\hline 5th level & 45 & 33.4 \\
\hline 7th level & 28 & 20.7 \\
\hline \multicolumn{3}{|c|}{ If she prefer to study part of course or whole course online again } \\
\hline yes & 67 & 49.4 \\
\hline no & 68 & 50.6 \\
\hline \multicolumn{3}{|c|}{ Number of courses study it through Blake board (Bb) } \\
\hline 1.00 & 24 & 17.8 \\
\hline 2.00 & 35 & 25.8 \\
\hline 3.00 and more & 76 & 56.4 \\
\hline \multicolumn{3}{|l|}{ Name of course on $\mathbf{B b}$} \\
\hline Medical surgical nursing & 24 & 17.8 \\
\hline Med-surgical and Islamic culture & 35 & 25.8 \\
\hline $\begin{array}{l}\text { Med-surgical, Islamic culture, and } \\
\text { Obstetric }\end{array}$ & 28 & 20.7 \\
\hline $\begin{array}{l}\text { Islamic culture, Arab, Physics, and } \\
\text { Biochemistry }\end{array}$ & 48 & 35.6 \\
\hline
\end{tabular}


Table (2): The descriptive statistics of the factors affecting e-learning experience as perceived by participants and perceived e-learner satisfaction

\begin{tabular}{|c|c|c|c|c|}
\hline Subscales of factor affecting e- learning & Min & Max & Mean \& SD & $\% *$ \\
\hline \multicolumn{5}{|l|}{ Learner dimension } \\
\hline 1. Learner attitude toward computers $(8-40)$ & 8 & 40 & $26.66 \pm 6.33$ & 66.7 \\
\hline 2. Learner computer anxiety $(4-20)$ & 4 & 20 & $10.93 \pm 3.67$ & 54.7 \\
\hline 3. Learner Internet self- Efficacy (0-12) & 0 & 12 & $9.01 \pm 2.67$ & 75.1 \\
\hline \multicolumn{5}{|l|}{ Course dimension } \\
\hline 4. E- learning course flexibility $(8-40)$ & 8 & 40 & $23.94 \pm 6.77$ & 59.9 \\
\hline 5. E- learning course quality $(3-15)$ & 3 & 13 & $7.93 \pm 2.44$ & 52.9 \\
\hline \multicolumn{5}{|l|}{ Technology dimension } \\
\hline 6. Technology quality $(4-20)$ & 4 & 20 & $12.84 \pm 3.48$ & 64.2 \\
\hline 7. Internet quality (4- 20) & 4 & 20 & $11.06 \pm 3.16$ & 55.3 \\
\hline \multicolumn{5}{|l|}{ Design dimension } \\
\hline 8. Perceived usefulness $(3-15)$ & 3 & 15 & $8.13 \pm 2.89$ & 54.2 \\
\hline 9. Perceived ease of use $(2-10)$ & 2 & 10 & $6.56 \pm 1.99$ & 65.6 \\
\hline \multicolumn{5}{|l|}{ Environmental dimension } \\
\hline 10. Diversity in assessment (1-5) & 1 & 5 & $3.07 \pm 1.15$ & 61.4 \\
\hline 11. Learner perceived interaction with others $(9-45)$ & 9 & 45 & $25.79 \pm 4.89$ & 57.3 \\
\hline 12. Perceived e- Learner satisfaction $(9-45)$ & 9 & 41 & $24.89 \pm 8.49$ & 53.3 \\
\hline
\end{tabular}

*Percentages of the mean divided by the maximum score

Figure1: participant students' perceived e-learning satisfaction levels

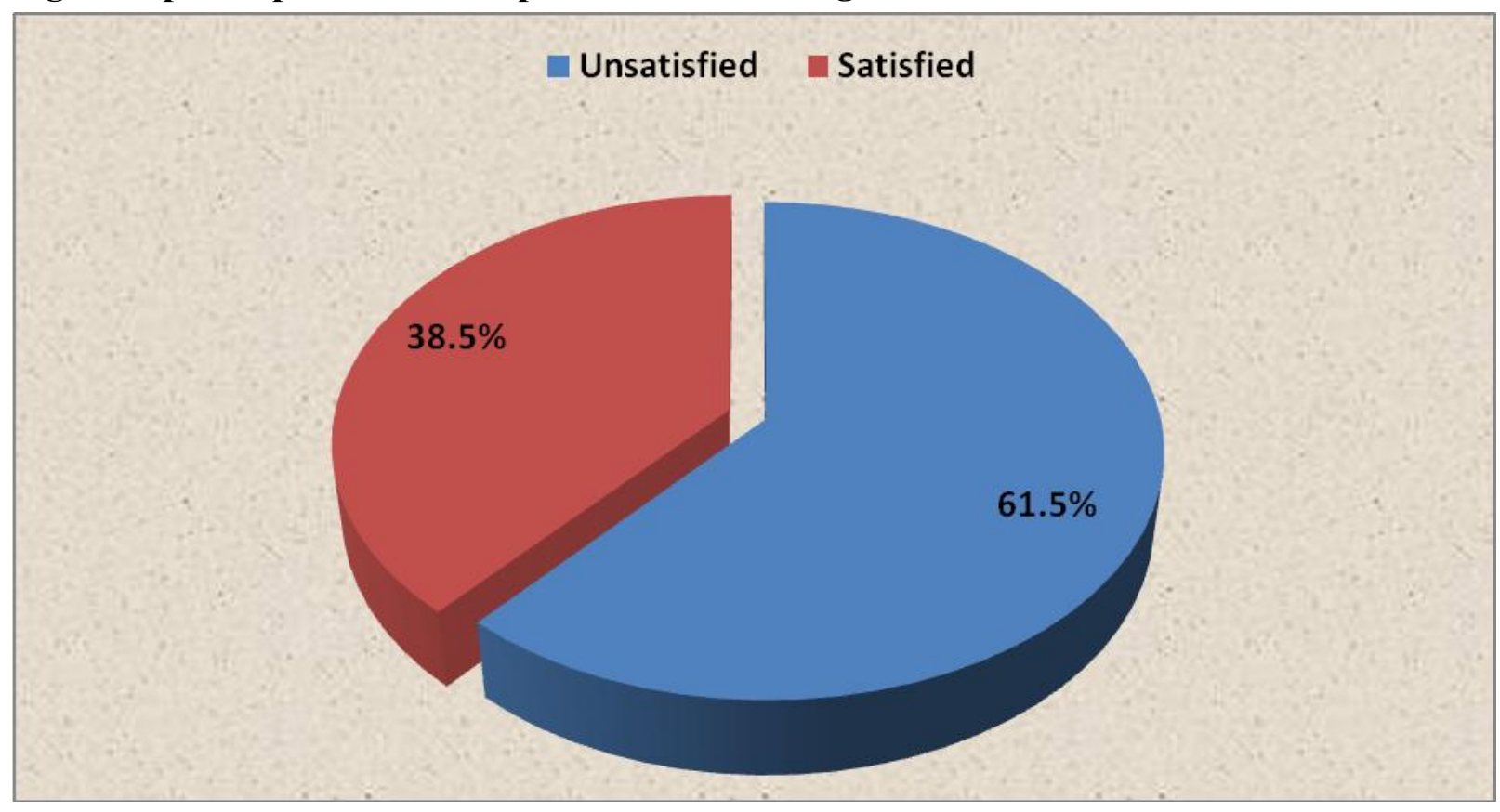


Table 3; the relationship between the independent variables (factors may affect elearner satisfaction) and perceived e- learner satisfaction (dependent varible)

\begin{tabular}{|c|c|c|}
\hline Factors may affect e- learner satisfaction & \multirow{2}{*}{$\begin{array}{l}\text { r \& P value } \\
\text { r } \\
\end{array}$} & \multirow{2}{*}{$\begin{array}{l}\text { Perceived e- Learner } \\
\text { satisfaction } \\
.188(*)\end{array}$} \\
\hline 1. Learner attitude toward computers & & \\
\hline & $\mathrm{P}$ value & .029 \\
\hline \multirow[t]{2}{*}{ 2. Learner computer anxiety } & $\mathrm{r}$ & $-.278(* *)$ \\
\hline & $\mathrm{P}$ value & .001 \\
\hline \multirow[t]{2}{*}{ 3. $\quad$ Learner Internet self- Efficacy } & $\mathrm{r}$ & .049 \\
\hline & $\mathrm{P}$ value & .570 \\
\hline \multirow[t]{2}{*}{ 4. E- learning course flexibility } & $\mathrm{r}$ & $.557(* *)$ \\
\hline & $\mathrm{P}$ value & .000 \\
\hline \multirow[t]{2}{*}{ 5. E- learning course quality } & $\mathrm{r}$ & $.656(* *)$ \\
\hline & $\mathrm{P}$ value & .000 \\
\hline \multirow[t]{2}{*}{ 6. Technology quality } & $\mathrm{r}$ & $.405(* *)$ \\
\hline & $\mathrm{P}$ value & .000 \\
\hline \multirow[t]{2}{*}{ 7. Internet quality } & $\mathrm{r}$ & .057 \\
\hline & $\mathrm{P}$ value & .510 \\
\hline \multirow[t]{2}{*}{ 8. $\quad$ Perceived usefulness } & $\mathrm{r}$ & $.408(* *)$ \\
\hline & $\mathrm{P}$ value & .000 \\
\hline \multirow[t]{2}{*}{ 9. $\quad$ Perceived ease of use } & $\mathrm{r}$ & $.363(* *)$ \\
\hline & $\mathrm{P}$ value & .000 \\
\hline \multirow[t]{2}{*}{ 10. Diversity in assessment } & $\mathrm{r}$ & $.459(* *)$ \\
\hline & $\mathrm{P}$ value & .000 \\
\hline \multirow[t]{2}{*}{ 11. Learner perceived interaction with others } & $\mathrm{r}$ & $.259(* *)$ \\
\hline & $\mathrm{P}$ value & .002 \\
\hline
\end{tabular}

** Correlation is significant at the 0.01 level (2-tailed).

* Correlation is significant at the 0.05 level (2-tailed).

\section{Discussion:}

There is increased pressure in universities and in the business community to use online methods for adult education ${ }^{(29)}$. With technological changes, educational institutions must also keep up in providing the ideal learning environment to meet changing demands, from changes in the traditional classroom, to the onset of the "Invisible Classroom." Information technology has created a bridge, so that many people who want to learn can now become "invisible" students ${ }^{(29)}$. Since e-learning is conducted using the Internet and World Wide Web, the learning environment becomes more complicated. Students' initial perceived satisfaction with technology-based e- learning will determine whether they will use the system continually.

Several elements influence student satisfaction in the online environment. Bolliger and Martindale (2004) ${ }^{(30)}$ identified three key factors central to online student satisfaction: the instructor, technology, and interactivity. Because faculty and students' satisfaction is one of the five pillars of quality ${ }^{(31)}$, it is important and needs to be continuously assessed to assure quality online educational experiences for faculty and students. This research try to identify critical factors influencing e-Learners' satisfaction. The results of this study indicated that learner' 
attitude toward computers learners' computer anxiety, e-learning course flexibility, e- learning course quality, technology quality, perceived usefulness, perceived ease of use, diversity in assessment, and learner perceived interaction with others are the critical factors affecting learners' perceived satisfaction. Much of researches indicate that learner attitude toward computers or information technology (IT) is an important factor in e- learning satisfaction ${ }^{(5,13,}$ 26, 16), this was in congruence with finding of this research which found a positive relationship between learners attitude toward computer and their satisfaction with their e- learning experience.. But those were incongruence with the finding of Sun, et al (2008) ${ }^{(19)}$.

According to Rezaei, Mohammadi, Asadi and Kalantary (2008) ${ }^{(32)}$, computer anxiety has a negative effect on students' intention to use an online learning system. The learners' anxiety can decrease their tendency to use online learning technologies ${ }^{(33)}$. Additionally, learners' anxiety seems to be a vital variable in relation to students' perceptions of online courses (Saade \& Kira, 2006). Those may justify and support the finding of the present study which ascertains that learner anxiety toward computers is one of the vital factors in perceived e-Learner satisfaction because there was a negative relationship between computer anxiety and perceived E learner satisfaction. This result corresponds also to some related research ${ }^{(20,16)}$. Piccoli et al. (2001) ${ }^{(16)}$ show, computer anxiety and fears of computer usage would certainly hamper learning satisfaction.

$\mathrm{Wu}$, Tennyson, \& Hsia, 2010, stated that a higher level of individual computer self-efficacy is positively associated with a higher level of learning performance which increases the use of e-learning ${ }^{(34)}$. Learners with high self-efficacy are more confident in accomplishing e-learning activities and improving their satisfaction ${ }^{(19,35)}$. Wang and Newlin (2002) ${ }^{(36)}$, from research on 122 students, conclude that students with higher self-efficacy are more inclined to adopt network-based learning and earn significantly better final grades. Liaw (2008) ${ }^{(35)}$ stated that the most critical factor that positively affected e-learners' satisfaction toward e-learning and e-learning usage was perceived self-efficacy of using e-learning. This is in contrast to the finding of the present study, which found that there was no relationship between learner internet self- efficacy and E learner satisfaction.

As regard to e- learning course flexibility and e-learning course quality, the findings of the present study indicated that e-learning course flexibility and e-learning course quality positively influence perceived e-learner satisfaction with e-learning. This was supported by Piccoli et al., 2001 ${ }^{(16)}$ who stated that, quality of well-designed e-learning programs is the precedent factor for learners when considering e-learning. Also Sun, et al (2008) ${ }^{(19)}$, stated in their study that "quality is another important factor influencing learning effects and satisfaction in e-learning". Additionally, Liaw (2008) ${ }^{(35)}$ stated that the e- learning system quality and multimedia instruction were significant predictors of perceived satisfaction with e-learning. In other words, system and multimedia quality seem to enhance learners' positive attitudes toward e-learning.

E-learning studies that applied the information system (IS) success model found that system quality and information quality significantly influence learner satisfaction ${ }^{(37-38)}$. Ozkan and Koseler (2009) ${ }^{(18)}$ found that system quality increased the effectiveness of learning management systems while content quality created value and learner satisfaction. Piccoli et al. $(2001)^{(16)}$ indicated that technology quality and Internet quality significantly affect satisfaction 
in e-learning as the higher the quality and reliability in IT, the higher the learning effects will be. This is in agreement with findings of the present study in the part of technology quality. It indicated that there was a significant relationship between the technology quality and perceived e-learner satisfaction with e-learning.

Lee (2010) ${ }^{(39)}$ found that perceived usefulness has a direct positive effect to the intention to use e-learning while perceived ease of use and perceived enjoyment have an indirect positive effect to intention to use. It is important for students to perceive online learning as useful. When students perceive online learning as such, the likelihood of them using online learning would be higher ${ }^{(40-41,32)}$. The higher the perceived usefulness of an e-learning system, the more satisfaction learners had. Perceived ease of use also has a significant impact on e-learner satisfaction. Users' notion of ease of use is an important antecedent to perceptions of satisfaction ${ }^{(19)}$. Those are in congruence with the findings of this research, which indicate that perceived usefulness and ease of use by learners significantly influences their satisfaction.

Factors relevant for a positive e-learning environment and e-learning satisfaction learners' perceived interactions with others, diversity in assessment, and perceived autonomy support $^{(5,42-44,19)}$. As illustrated by Thurmond et al. (2002) (17), when diversified evaluation methods exist to assess effectiveness of e-Learning, students' activities and processes might be corrected or improved through multiple feedbacks to achieve better performance. A variety of assessment methods enable instructors to canvass learning effects from different aspects so that instruction may be more effective. As for students, diversified assessment methods motivate them to exhibit their best efforts in different evaluation schemes so as to proceed with elearning activities seriously and effectively. Hence, higher learning satisfaction occurred. This is in agreement with the finding of the present study which indicated that there was a strong association between diversity in assessment and nursing students' satisfaction with e-learning.

In addition, the finding of the present study indicated that there was a strong association between learner perceived interaction with others and nursing students' satisfaction with e-learning. This finding supported by Arbaugh $(2000){ }^{(22)}$ who suggests that the more learners perceive interaction with others, the higher the e- learning satisfaction. In a virtual learning environment, interactions between learners and others or course materials can help solve problems and improve progress. Interacting electronically could improve learning effects ${ }^{(16)}$.

Furthermore, the present study reported that more than half of participants unsatisfied with their experience with $\mathrm{Bb}$ or e- learning as measured by e- learning satisfaction scale. This in accordance with study done by Singleton, Song, Hill, Koh, Jones and Barbour (2004), reported that students seemed to prefer to attend class rather than take the course online because they are more familiar with the traditional teaching and learning environment. Moreover, students felt that questions could be resolved immediately in a traditional classroom setting ${ }^{(45)}$. This may be interpreted by the student is generally more isolated from other students in the virtual learning environment. Students do not have the chance to socialize physically with other classmates. With the lack of face-to-face communication, students can feel that they are "left in the dark," unless they communicate with the educator and receive prompt responses. Also common concerns that affect many online students are the issues of time and effort. Students involved in online learning typically spend more time researching 
and reading just to get the essence of the topics. In a typical classroom setting, students can gather the main essence of a topic by listening to the instructors' presentation ${ }^{(46)}$.

\section{Conclusion;}

The results revealed that learners' attitude toward computers, learners' computer anxiety, e-learning course flexibility, e-learning course quality, technology quality, perceived usefulness, perceived ease of use, diversity in assessment, and learner perceived interaction with others are the critical factors affecting learners' perceived satisfaction. Also this study indicated that more than the half of participants unsatisfied with their experience with $\mathrm{Bb}$ or e-learning experience as measured by e-learning satisfaction scale. The results show institutions how to improve learner satisfaction and further strengthen their e- learning implementation.

\section{Recommendations;}

Based on the previous results the researchers made the following recommendations

1. According to this study, learners' anxiety also hampers their satisfaction. Helping students build their confidence in using computers will make e- learning more enjoyable.

2. Course content should be relevant, logically organized, easy to use, carefully designed, and presented sparingly.

3. Technological design plays an important role in students' perceived usefulness and eases of use of a course and will have an impact on students' satisfaction so Skills training for learners-IT, information literacy, e- learning study skills, time management are very essentials.

4. Presence of a range of skilled staff-IT staff, design staff, trainers, support staff, administrators will be helpful.

5. Also when instructors are committed to e-learning and exhibit active and positive attitudes, their enthusiasm will be perceived and further motivate students.

6. Easy access to technology for both trainers and learners.

7. The administrative strategy should properly identify different assessment schemes to evaluate learning effects more diversely. In addition to instructors' evaluations of student performance, self-assessment or even peer assessment could be incorporated in the systems, enabling students to monitor their own achievements.

8. One of many advantages of online education is its flexibility in which learners choose the most suitable learning methods to accommodate their needs. At all times, system administrators should ensure all system functionalities are available.

9. Periodic assessment of system performance and loading will provide better and uninterrupted operational environments to enhance student satisfaction with e-Learning.

10. Institutions not only have to provide training to the faculty in empowering them with the tools and skills to carry out their educational roles properly, but the faculty itself has to be mentally prepared to tackle the obstacles hindering their traditional practices in imparting knowledge. 


\section{References}

1. Yee H., Luan W., Ayub A., \& Mahmud R. (2009). A Review of the Literature: determinants of Online Learning among Students. European Journal of Social Sciences. 8, 2. 246.

2. Andrusyszyn, M.A., Moen, A., Iwasiw, C., Ostbye, T., Davie, L., Stovring, T., et al. (2000). Evaluation of electronic collaborative international graduate nursing education: The Canada-Norway experience. Journal of Distance Education, 15, 52-70.

3. Billings, D. (2000). A framework for assessing outcomes and practices in Web-based courses in nursing. Journal of Nursing Education, 39, 60-68.

4. Siritongthaworn, S., Krairit, D., Dimmitt, N. J., \& Paul, H. (2006). The study of e- learning technology implementation: a preliminary investigation of universities in Thailand. Education and Information Technologies. 11(2), 137-160.

5. Arbaugh, J. B. (2002). Managing the on-line classroom: a study of technological and behavioral characteristics of web-based MBA courses. Journal of High Technology Management Research, 13, 203-223.

6. Selim, H. M. (2007). Critical success factors for e- learning acceptance: confirmatory factor models. Computers \& Education, 49(2), 396-413.

7. VandeVusse, L. \& Hanson, L. (2000). Evaluation of online course discussions: Faculty facilitation of active student learning. Computers in Nursing, 18, 181-183.

8. Ruiz, J. G., Mintzer, M. J., \& Leipzig, R. M. (2006). The impact of e- learning in medical education. Academic Medicine, 81(3), 207-212.

9. Welsh, E. T., Wanberg, C. R., Brown, K. G., \& Simmering, M. J. (2003). E-learning: emerging uses, empirical results and future directions. International Journal of Training and Development, 7(4), 245-258.

10. Zhang, D., Zhao, J. L., Zhou, L., \& Nunamaker, J. F. (2004). Can e- learning replace classroom learning? Communications of the ACM, 47(5), 74-79.

11. Childs, S., Blenkinsopp, E., Hall, A., \& Walton, G. (2005). Effective e- learning for health professionals and students - barriers and their solutions. A systematic review of the literature - findings from the HeXL project. Health Information and Libraries Journal, 22(Suppl. 2), 20-32.

12. Bhuasiri, W., Xaymoungkhoun, O., Zo, H., Rho, J., \& Ciganek., A. (2012) Critical success factors for e-learning in developing countries: A comparative analysis between ICT experts and faculty. Computers \& Education. 58, 843-855.

13. Arbaugh, J. B., \& Duray, R. (2002). Technological and structural characteristics, student learning and satisfaction with web-based courses - An exploratory study of two on-line MBA programs. Management Learning, 33(3), 331-347.

14. Chen, W. L. C., \& Bagakas, J. G. (2003). Understanding the dimensions of self-exploration in web-based learning environments. Journal of Research on Technology in Education, 34(3), 364-373.

15. Lewis, C. (2002). Driving factors for e-Learning: an organizational perspective. Perspectives, 6(2), 50-54. 
16. Piccoli, G., Ahmad, R., \& Ives, B. (2001). Web-based virtual learning environments: a research framework and a preliminary assessment of effectiveness in basic IT skill training. MIS Quarterly, 25(4), 401-426.

17. Thurmond, V. A., Wambach, K., \& Connors, H. R. (2002). Evaluation of student satisfaction: determining the impact of a web-based environment by controlling for student characteristics. The American Journal of Distance Education, 16(3), 169-189.

18. Ozkan, S., \& Koseler, R. (2009). Multi- dimensional students' evaluation of e-learning systems in the higher education context: an empirical investigation. Computers \& Education, 53(4), 1285-1296.

19. Sun, P., Tsai, R., Finger, G., Chen, Y., \& Yeh, D. (2008). What drives a successful e-Learning? An empirical investigation of the critical factors influencing learner satisfaction. Computers \& Education. 50, 1183-1202.

20. Barbeite, F., \& Weiss, E. (2004). Computer self-efficacy and anxiety scales for an Internet sample: testing measurement equivalence of existing measures and development of new scales. Computers in Human Behavior, 20, 1-15.

21. Marakas, G. M., Yi, M. Y., \& Johnson, R. D. (1998). The multilevel and multifaceted character of computer self-efficacy: Toward clarification of the construct and an integrative framework for research. Information System Research, 9(2), 126-163.

22. Arbaugh, J. B. (2000). Virtual classroom characteristics and student satisfaction with internet-based MBA courses. Journal of Management. Education, 24(1), 32-54.

23. Webster, J. \& Hackley, P. (1997). Teaching effectiveness in technology-mediated distance learning. Academy of Management Journal, 40(6), 1282-1309.

24. Pituch, K. A., \& Lee, Y. K. (2006). The influence of system characteristics on e- learning use. Computers \& Education, 47, 222-244.

25. Cao, Q., Griffin, T. E., \& Bai, X. (2009). The importance of synchronous interaction for student satisfaction with course web sites. Journal of Information Systems Education, 20(3), 331-338.

26. Hong, K. S. (2002). Relationships between students' and instructional variables with satisfaction and learning from a Web-based course. Internet and Higher Education, 5, 267-281.

27. Swan, K. (2001). Virtual interaction: design factors affecting student satisfaction and perceived learning in asynchronous online courses. Distance Education, 22(2), 306-331.

28. Wang, Y. S. (2003). Assessment of learner satisfaction with asynchronous electronic learning systems. Information \& Management, 41, 75-86.

29. Colvin Clark, R., \& Kwinn, A. (2007). Meet the new virtual classroom. In The new virtual classroom: Evidence-based guidelines for synchronous e-learning (pp. 3-24) San Francisco, CA: John Wiley \& Sons Inc.

30. Bolliger, D.U., \& Martindale, T. (2004). Key factors for determining student satisfaction in online courses. International Journal on E-Learning, 3(1), 61-67.

31. Sloan Consortium. (2008). Faculty satisfaction. Retrieved August 28, from http://www.sloan-c-wiki.org/wiki/index.php? 
32. Rezaei, M., Mohammadi, H. Asadi, A., \& Kalantary, K. (2008). Predicting e-learning application in agricultural higher education using Technology Acceptance Model. Turkish Online Journal of Distance Education, 98(1), 85-95.

33. Habibah $\mathrm{Hj}$. Lateh \& Arumugam Raman. (2005). Web-based Map Reading in Geography. In Hanafi Atan, Rozhan M. Idrus, Saw K. G., Fong, S. F. \& Meor Azli Ayub. (Eds.) Inovasi Teknologi Instruksional dalam Pengajaran dan Pembelajaran (pp.404-410). Malaysia.

34. Wu, J.-H., Tennyson, R. D., \& Hsia, T.-L. (2010). A study of student satisfaction in a blended e-learning system environment. Computers \& Education, 55(1), 155-164.

35. Liaw S. (2008). Investigating students' perceived satisfaction, behavioral intention, and effectiveness of e-learning: A case study of the Blackboard system. Computers \& Education 51, 864-873).

36. Wang, A. Y., \& Newlin, M. H. (2002). Predictors of web-student performance: the role of self-efficacy and reasons for taking an on-line class. Computers in Human Behavior, 18, 151-163.

37. Chiu, C.-M., Chiu, C.-S., \& Chang, H.-C. (2007). Examining the integrated influence of fairness and quality on learners' satisfaction and web-based learning continuance intention. Information Systems Journal, 17(3), 271-287.

38. Roca, J. C., Chiu, C.-M., \& Martínez, F. J. (2006). Understanding e-learning continuance intention: an extension of the technology acceptance model. International Journal of Human-Computer Studies, 64(8), 683-696.

39. .Lee, M.-C. (2010). Explaining and predicting users' continuance intention toward e-learning: an extension of the expectation-confirmation model. Computers \& Education, 54(2), 506-516.

40. Ong, C. H. \& Lai, J. Y. (2006). Gender differences in perceptions and relationships among dominants of e- learning acceptance. Computers in Human Behavior. 22(5), 816-829.

41. Tung, F.C., \& Chang, S.C. (2008). An empirical investigation of students' behavioral intentions to use the online learning course websites. British Journal of Educational Technology, 39(1), 71-83.

42. McLeod, A., Pippin, S., \& Mason, R. (2009). Individual taxpayer intention to use tax preparation software: examining experience, trust, and perceived risk. Journal of Information Science and Technology, 6(1), 25-44.

43. Roca, J. C., \& Gagné, M. (2008). Understanding e-learning continuance intention in the workplace: a self-determination theory perspective. Computers in Human Behavior, 24(4), 1585-1604

44. Sørebø, Ø, Halvari, H., Gulli, V. F., \& Kristiansen, R. (2009). The role of self-determination theory in explaining teachers' motivation to contribute to use e-learning technology. Computers \& Education, 53(4), 1177- 187.

45. Singleton, E., Song, L., Hill, J., Koh, M., Jones, F. \& Barbour, M. (2004). Online learning: Perceptions of useful and challenging characteristics. In G. Richards (Ed.). Proceedings of World Conference on E- learning in Corporate, Government, Healthcare, and Higher Education (pp. 946-950). 
46. Bouhnik, D., \& Marcus, T. (2006). Interaction in distance- learning courses. Journal of the American Society Information Science and Technology, 57 (3), 299-305). 